\title{
Community Involvement Strategies in Quality Legal Counseling
}

\author{
Oki Wahju Budijanto ${ }^{1, *}$ Josefhin Mareta ${ }^{1}$, Junaidi Abdillah ${ }^{1}$ \\ Zaihan H. Anggayudha ${ }^{1}$ \\ ${ }^{1}$ Research and Development Agency on Law and Human Rights of the Ministry of Law and Human Rights of The \\ Republic of Indonesia \\ ${ }^{*}$ Corresponding author.Email: oki_olive@yahoo.com
}

\begin{abstract}
The strategic role of the National Law Development Agency (BPHN) in raising legal awareness has been carried out by various methods, namely direct legal counseling and indirect legal counseling. The results of the implementation of legal counseling were not as expected. Considering this strategic role, this research was conducted with an emphasis on how the strategy to create a better legal awareness of the community. The purpose of this research is to offer new strategies that can be applied by BPHN to create legal awareness. The normative juridical research method is used in this study with primary and secondary legal material. The technique of collecting data is through literature study which is then analyzed qualitatively. It was found that BPHN has so far still viewed the community as an object of counseling by assessing legal awareness from the formation of a lawaware village. Therefore, a community involvement strategy is needed in the form of a village / sub-district task force that has an extension work program using technology. Periodic evaluation of the performance of the task force is required to be directed at increasing legal awareness.
\end{abstract}

Keywords: community involvement, legal counseling, legal awareness.

\section{INTRODUCTION}

Considerate the law is a determining factor for the high and low number of crimes that occur in society. Poor understanding of the law in the community can lead to an increase in the number of crimes that occur in an area, and vice versa, a high considerate of the law in the society will increase the legal awareness of the community that results in a reduced number of crimes that occur.

To build legal awareness in the community, since the 1980's the Ministry of Law and Human Rights has launched the Law-Awareness Village or Village program. This program intends to raise awareness of the village or village community regarding formal and customary laws and social norms. This program is carried out through the socialization of legal and traditional products by the Regional Office of the Ministry of Law and Human Rights to residents of Kelurahan or Village.
Better legal awareness of the community needed every member of the community to realizes and lives up to their rights and obligations as citizens. Besides that, to recognize a lawful culture in attitudes and behaviors that are aware and obedient to the law and respect human rights, BPHN organizes a legal counseling program. Legal counseling is one of the preventive efforts or preventing the occurrence of crime by providing law knowledge and understanding to the public. To measure the level of success of the legal counseling program, BPHN assessed the number of law-aware villages. But it has not been able to answer the level of public legal awareness.

Based on data compiled by BPHN, the number of law-aware villages or sub-districts that has inaugurated until January 2020 was 5,744 village or sub-district.[1] During the period 2016-2018, the number of incidents of crime or criminal acts in Indonesia tended to fluctuate. Based on data from the National Police of the Republic of Indonesia, it shows that the crime rate incidents (entire crime) in 2016 was 357,197 incidents, decreased to 336,652 incidents in 
2017, and decreased in 2018 to 294,281 incidents.[2] Then there was another decline in 2019 with the number of crimes reported as 222,543 cases.[3]

This failure did not occur in 2020. The crime rate that occurred in Indonesia increased by 38.45 percent based on data in the 23rd and 24th week of 2020. There was an increase of 1,632 cases. Details, 4,244 cases at week 23, and 5,876 cases at week 24. The Head of the Public Information Bureau (Karo Penmas) of the Public Relations Division of the National Police Brigadier General (Brig. Gen.) Awi Setiyono at the National Police Headquarters, Tuesday, June 16, 2020, said five dominant cases were increasing, the first case namely weighted theft (nozzle), which is there were 693 cases.

The second case that embezzlement. At week 23, there were 295 cases, while in week 24, there were 421 cases. "So that it rose to 126 cases or 42.71 percent." The third case was the theft of a two-wheeled motorcycle. In the 23rd week, there were 114 motorbike thefts, while on the 24th week, there were 226 cases. There was an increase of 112 incidents or 98.25 percent. Narcotics crimes also rose from 649 at week 23 and 743 incidents in week 24. Lastly, the gambling case. Bhayangkara Corps recorded 52 gambling cases at week 23 and 104 at week 24. There was an increase of 52 incidents or 100 percent.[4]

The increase in cases in 2020 was predicted by community activities when the transitional large-scale social restrictions (PSBB) also increased. Along with development community activity, the criminals also took advantage of the situation to carry out their actions. The Chancellor of Paramadina University, Firmanzah, gave his views regarding the impact of Covid-19 on the world economy and Indonesia. Covid-19 has had an entirely significant impact beginning at labor to public consumption. This condition will also have a burden on unemployment, both due to termination of employment, termination of employment contracts, employees whose salaries are not paid or have their payments underpaid. Today's world economy is indeed too delicate for the sustainability of living things.

In this case, it can seem that positive law, both when is formed and when applied in concrete cases in the field, will come into contact with time and space factors. The spatial aspect refers to the place (location), where the legal subjects are and interact with others and the natural surroundings. The time factor refers to a certain period when this legal subject is alive and active. These two factors frame human activities as individual beings and social beings so that these space and time factors can shape the behavior patterns of community members. Customs and habits are examples of the behavior patterns of people who are in the same space at a time similarity shapes culture. By developing a legal culture at all levels of the community, it hoped that could create awareness and legal compliance that turn can reduce the crime rate.

There are three ways to deal with crimes that preemptive, preventive, and repressive. Crime prevention is proactive and reactive activities directed at both the perpetrator and the victim and in the social and physical environment, which are carried out before or after a crime occurs.[5]

Thus, it is reasonable to suspect that the legal education programs that have been implemented have not been able to reduce the crime rate or criminal acts. Previous research results have shown that the legal counseling conducted by BPHN has not been optimal. As research conducted by Yul Ernis, where there is still a lack of implementation of community legal counseling carried out by BPHN and the regional office of the Ministry of Law and Human Rights and other relevant agencies. The establishment of a Legal Awareness Village is still ineffective in increasing legal awareness of the community and reducing crime rates. Therefore, this research is important to do in order to develop a legal extension strategy that has measurable results for increasing legal awareness. The purpose of this research is to produce new strategies in the pattern of legal counseling that can be offered to the National Law Development Agency.

Based on the series of phenomena previously described, the formulation of the problem is what is the role of legal counseling of BPHN in tackling crime and what strategies offered in the pattern of legal counseling?

\section{RESEARCH METHOD}

This research is juridical-normative research. The research method based on materials primary and secondary law. The approach is a qualitative approach to collect information, formulate relevant questions, and then link it to the given theories and principles. The technique of data collection was through the study of literature by reviewing documents, regulations, books, and other literature.

Then based on the obtained data regarding legal counseling, are analyzed qualitatively. Qualitative analysis will analyze and compare the findings with theoretical research results that are relevant to the research question. Qualitative analysis is a description based on the theory of the research results. Further, it 
analyses how the effort to prevent crime, the role of legal counseling of BPHN in tackling crime through a non-penal approach, and community involvement strategy in quality legal counseling.

\section{FINDINGS AND DISCUSSION}

\subsection{Legal Awareness and Legal Culture}

Law is a cultural product, where culture is a blueprint of acts that gives value to what behavior should do and what is prohibited. Thus, culture includes a system of goals and values. Law is a reflection or a reflection of the benefit contained in society.

Legal awareness is the final result of law knowledge, law understanding, law attitudes, and law behavior that live in society. People who are aware of the law certainly understand what legal means, what should do, and what should not do. Legal awareness in the community is not a one-time process, but rather a series of processes that occur step by step as follows:[6]

\section{a. Legal knowledge stage}

In this case, it is someone's knowledge regarding assertive behavior that is regulated by written law, namely about what is prohibited or what is permissible.

\section{b. Legal understanding stage}

The amount of information a person has regarding the content of a legal rule (written), namely regarding the content, purpose, and benefits of the regulation.

\section{c. Legal attitude stage}

It is a tendency to accept or reject the law because of appreciation or conviction that the law is beneficial or not beneficial to human life. In this case, there is already an element of appreciation for the rule of law.

\section{d. Legal Behavior Pattern Stage}

Whether or not a law rule is applicable in society. If it rules of law applies, the extent to which it applies, and the extent to which the community obeys it.

From the four stages of legal awareness, indicators built from:

a. Legal knowledge, where the dimensions included in law knowledge are:

1) Knowledge of the law that governs a matter.
2) Where did the awareness come starting.

3) What matters are regulated.

b. Legal Understanding

1) Be able to restate the concept of a law rule.

2) Able to classify the objects of a law rule.

3) Be able to provide examples.

4) Able to develop the requirements of a law rule.

c. Legal Attitude

Response to a concept of the rule of law.

\section{d. Legal Behavior Pattern}

1) Identifying various objects in connection with the actions to be taken related to law.

2) Choosing from different items in connection with the activity to be taken related to law.

Lawrence Friedman further explained that legal culture or culture is a value factor that creates differences in law live in society. So that lawful culture is the attitudes and values possessed by the community that is related to law and its institutions, both of which are positive nor negative.[7] The fact that often happens repeatedly that then forms the same behavior pattern over and over again eventually becomes a legal norm. Legal norms will felt binding when burdening the obligations of those who carry them out, where if someone violates the bond, they will sanction.

Lexically, "culture" is defined as thoughts, intellect, customs, or something that has become a habit that is difficult to change. The word "culture" that interpreted as the result of activities and the creation of the human mind (mind) such as beliefs, arts, and customs. It clarifies as the overall knowledge of humans as social creatures used to understand the environment and their experiences and guide their behavior.[8]

Public legal awareness is a kind of bridge that connects legal regulations with the law behavior of community members. Lawrence Friedman is more inclined to call it part of the lawful culture that values, attitudes that affect the operation of law. The concept of legal awareness contains an element of value. This course has lived up to by the community since childhood and has been regulated and ingrained. This institutionalization process eventually becomes the guideline that is maintained by the community and impart through the socialization process.[7] 
Furthermore, what is lived and institutionalized is manifested in the form of norms that become standards for citizens to behave. The behavior of the community members contains elements of values that lived for a long time, and this is what affects the operation of the law in society.[7]

Public legal awareness is an incarnation of a community law culture that requires structured and programmed efforts over a period. The development of lawful culture is part of a cultural strategy. That is thought of by leaders of the Indonesian nation, which is echoed by the term "nation and character-building." A healthy legal culture must demonstrate opening from definite things when the law is an appliance in the short, medium, and long term. Society must change for the better with a new legal culture that must be created and achieved. However, such a healthy and ideal lawful culture cannot possibly realize without being preceded by concrete things that must in a short period.

\subsection{Efforts to Prevent Crime}

To anticipate that criminal acts do not occur in society, the government should prohibit the committing of criminal acts in the form of a legal system that will later become a binding norm and control the entire community. The rule of law prohibits every individual in a community group from committing a criminal act that manifests in the form of statutory regulations or other guidelines that have become general principles in a legal system. According to Barda Nawawi Arief, the formation of law rules to determine what actions should prevent from happening in society is firmly relates to building community welfare. Thus, efforts to eradicate criminal acts are an inseparable part of efforts to protect society in realizing social welfare.[9]

Combating crime is eliminating the causes or conditions that give rise to a felony. Crime prevention is commonly referred to as criminal adroit can cover an adequately broad scope.[10]

In general, the prevention of crime that has a state by G.P Hoefnagels can group into two parts, namely the handling of penalties and non-penal crimes. The penal policy is a form of crime prevention that focuses on repressive actions after the occurrence of a crime. The non-penal approach emphasizes more on the preventive force before the circumstance of a criminal act. According to the viewpoint of criminal politics, the non-penal administration is the most strategic crime prevention policy because it is preventive before the crime occurs.
In various United Nations congresses on "The Prevention of Crime and Treatment of Offenders," strategic efforts were made to address the causes of crime. The most strategic non-penal achievement is all efforts to make the community a social and healthy environment from the factors that cause crime.[11] That means the society whit all its potentials should use as an antidote to an atrocity that is an integral part of all criminal politics.

\subsection{Role of the Ministry of Law and Human Rights in Tackling Crime through Non- Penal Approach}

The Ministry of Law and Human Rights in realizing the government's goal in the 4th Nawacita program is "Rejecting weak countries by reforming systems and law enforcement that are free of corruption, dignified and trustworthy."[12] assist the President in administering the state.

The Ministry of Law and Human Rights, carries out one of its affairs is the National Law Development. Based on the previous intentions, according to the researcher's view, it is to prevent crime through legal education to the public. Furthermore, criminology examines the theories that used as the basis for efforts to tackle crime, in which M. Hamdan divides efforts to tackle the crime with 2 (two) routes:

\section{a. Penal Approach}

Namely by applying the punishment carried out by part of the Integrated Criminal Justice System.

\section{b. Non Penal Approach}

Prevention without punishment, including the application of administrative sanctions and civil sanctions

At point $b$, this is in line with the duties of BPHN, the Center for Legal Counseling and Legal Aid in the Field of Legal Counseling and the Field of Legal Culture. The Regulation of the Minister of Law and Human Rights of the Republic of Indonesia Number 29 of 2015 dated 29 September 2015 concerning the Organization and Work Procedure of the Ministry of Law and Human Rights of the Republic of Indonesia Article 1070 states that the field of legal counseling has the task of implementing national legal education. Farther Article 1074 accompaniment that the area of lawful culture has the task of carrying out the civilization of the law and the formation of a lawconscious village.

In line with this nawacita and criminological theory, it is very appropriate to prevent crime through 
non-penal channels carried out by the Center for Legal Counseling and Legal Aid at the Ministry of Law and Human Rights. That is states in the Regulation of the Minister of Law and Human Rights of the Republic of Indonesia Number: M.01-PR.05.08.10 of 2007 concerning Amendments to the Regulation of the Minister of Law and Human Rights Number: M.01PR.08.08.10 of 2006 concerning the Pattern of Legal Counseling. Article 11 accompaniment "Legal counseling carried out by functional legal counselors and or persons who have knowledge and expertise in the field of law and can convey information or explanations about the material being taught clearly and correctly to the community taught." In that article, it is quite clear that building public legal awareness is not only carried out by a legal counselor but can also be done by people who have knowledge and expertise in the field of law and can convey the material taught.

Therefore, its implementation requires synergy between units within the Ministry of Law and Human Rights. Building public legal awareness is not only the task of BPHN but all units, regional offices, and technical implementing units within the Ministry of Law and Human Rights. They have the same duty in realizing the vision of the Ministry of Law and Human Rights that society gets legal certainty. One of the efforts made so that the community can obtain legal certainty is to first build community legal awareness through the initiative of a legal counselor.

BPHN has conducted legal counseling in various ways and methods. The method of legal counseling is direct legal counseling and indirect legal counseling. The law counseling method is a way of delivering legal information from legal counselors to the target of law extension. Direct legal counseling carries out by meeting face to face between the extension agent and the instructor. Indirect legal counseling is legal counseling conducted through printed and electronic media. One of the law counseling through electronic media is television, both Indonesian Republic Television and private television.

The measure of community legal awareness is measured based on the results of the achievements in establishing a law-aware village. There are 5,744 (five thousand seven hundred forty-four) villages that have formed through Indonesia, out of a total of approximately 81,000 (eighty-one thousand) villages throughout Indonesia. Attention to the national priorities that have been set in the 2019 Government Work Plan, in which the National Law Development Program has several preferences. The 2019 national priorities are then translated into strategic targets to achieve, one of which is the realization of public legal awareness. In measuring the law's attention of the community, an indicator of the number of law-aware villages formed in all 175 village use.

The legal counseling has carried out (Integrated Legal Counseling, Legal Awareness Gathering, Mobile Legal Counseling using Mobile Counseling Cars), as well as indirect Legal Counseling (through Talkshows on Television or Radio) to support the indicators for the formation of a law-aware village. The Concurrent Legal Counseling (luhkumtak) in Jabodetabek on March 26, 2019, simultaneously in 15 locations related to the material "Law 11 of 2012 concerning the Juvenile Criminal Justice System" implemented by all Law Counselor, where the participants involved, especially throughout Jabodetabek are more than 900 (nine hundred) students and the general public, 900 (nine hundred) people. Other legal extension activities that have to carry out are as many as 443 (four hundred and fortythree) through various extensions media. Concerning law counseling media, 3 (three) law extension media have been made, the results of which use to support the implementation of legal education, namely: community empowerment media in the form of indirect counseling through printed media, short films, and documentary films, and website, application and network media social.[13]

Munir Fuady's opinion that legal awareness in society is not a one-time process but a series of actions. That occurs step by step (knowledge, understanding, attitudes, and patterns of legal behavior), then public legal awareness is not seen in quantity but rather quality. Legal awareness is an abstract conception in humans of the harmony between order and order or what is appropriate. Therefore, community legal awareness is the output of the process of law extension activities marked by a sense of respect for law through practice in the field. The choice of methods and techniques of communicative and attractive legal counseling is crucial in touching the conscience of the community so that it can raise legal awareness.

That assuredly reinforced from the results of the conclusions of research conducted by Yul Ernis, where there is still a lack of implementation of community legal counseling carried out by BPHN and the regional office of the Ministry of Law and Human Rights and other relevant agencies. The results are not as expected. the implementation of community legal counseling has constraints, among others: Limited number and capacity of human resources, inadequate facilities and infrastructure, insufficient budget. Then, the law extension method carries out with the direct law counseling method in the form of lectures, which 
is not very attractive to the public that it has not had a significant effect on increasing the legal awareness of the community.[14]

The thesis of Tri Novianti Wulandari stated that of the 29 (twenty-nine) villages in Pontianak City has been designated as Village Legal Awareness, but still not able to indicate significant effectiveness in increasing community legal compliance if connected with the target of meeting the criteria. To be designated as a Village Legal Awareness, especially with an indication of an increasing crime trend in Pontianak City. During the last 2 (two) years, 2015 to 2016, there has been an increase in social security disturbances by 2,977 , increasing to 3,445 cases. The factors that cause the ineffectiveness of the lawconscious village in increasing legal compliance of the community include budget constraints to carry out guidance and activities in the framework of establishing and fostering a law-aware suburb in Pontianak, limited facilities and infrastructure, human resources not yet built. Communication patterns between stakeholders, coordination, and communication are less synergistic between related agencies in fostering a legal awareness village.[15]

\subsection{Community Involvement Strategy in Quality Legal Education}

Participation is very important in building a community legal culture. This is necessary because there is mental and emotional involvement of a person in a group situation that encourages them to achieve group goals and take responsibility for the group.[16] The development of a community legal culture certainly requires a participatory strategy based on a balance between interests.

Based on the opinion of Sherry R Arnstein (The Ladder of Citizen theory) which divides the levels of community participation in development programs implemented by the government, there are 8 (eight) levels of participation as follows:[17]

a. citizen control, society can participate in and control the entire decision making process.

b. delegated power, at this level the community is given the authority to make decisions on certain plans.

c. partnerships, community have the right to negotiate with decision makers or the government, by mutual agreement, the power is shared between the community and the government. d. The placation, of power holders (government) needs to appoint a number of people from the affected sections of society to become members of a public body, where they have certain access to the decision-making process.

e. Consultation, public is not only notified but also invited to share opinions, although there is no guarantee that the opinions expressed will be taken into consideration in decision making.

f. Informing, power holders only provide information to the public regarding proposed activities, the community is not empowered to influence the results.

g. Therapy, powerholder provides reasons for the proposal by pretending to involve the community.

h. Manipulation, is the lowest level of participation, where the community is only used by name.

In the context of this research requires community participation in the form of cooperation between all interested parties.

The strategy (grand design) of legal counseling is prepared by referring to the strategic plan that has established by the Ministry of Law and Human Rights as well as the work program of BPHN, which adjusts to the development of community dynamics and advances in information technology. The implementation of its activities uses more innovations and an increase in the use of more modern communication media twain electronic media, printed media, and other media, including in-law education techniques and methods.[18]

The experience, it can conclude that the socialization of the law is one that should seriously improve through good national, patterned and structured coordination by utilizing all supporting infrastructure such as active community participation, electronic and non-electronic media, and channels. Other channels as the use of information technology and others.[18]

In raging people's lives due to the current outbreak of the Covid-19 pandemic, it has brought global uncertainty. This condition must be faced with optimism and continue to innovate in overcoming this problem. The problem of the Covid-19 diffuse bearing information technology has a crucial role as well as a solution to overcome this uncertainty. Therefore, the use of information technology in extension can use as a reliable alternative. This statement support by the research of Nanik A Purwatiningsih, Anna F, and Retno Sri Hartati M, where more extension workers 
use the internet in compiling reports, making materials, amass programs, and designing extension methods. So the performance of extension workers in preparation for agricultural extension activities, the implementation of agricultural extension activities, and the evaluation of agricultural extension will be better.[19]

The best experience made by the Ministry of Social Affairs in conducting counseling that implemented strategies:[20]

a. Increasing social capacity and social responsibility of the community, meaning that social counseling must design as a community empowerment process and a process of strengthening the social capability and social responsibility.

b. In order to create good governance, social welfare programs need to be supported by improving the quality of professional human resources.

c. Increased community participation, meaning that social counseling is direct at increasing community participation in the implementation of the National Priority program.

Referring to The Ladder of Citizen theory and based on several previous research results, as well as paying attention to Article 11 of the Regulation of the Minister of Law and Human Rights of the Republic of Indonesia Number: M.01-PR.05.08.10 of 2007 concerning Amendments to the Regulation of the Minister of Law and Human Rights of the Republic of Indonesia Number: M. 01-PR.08.08.10 of 2006 concerning the Pattern of Legal Counseling, the researcher offers a concrete and measurable community involvement strategy.

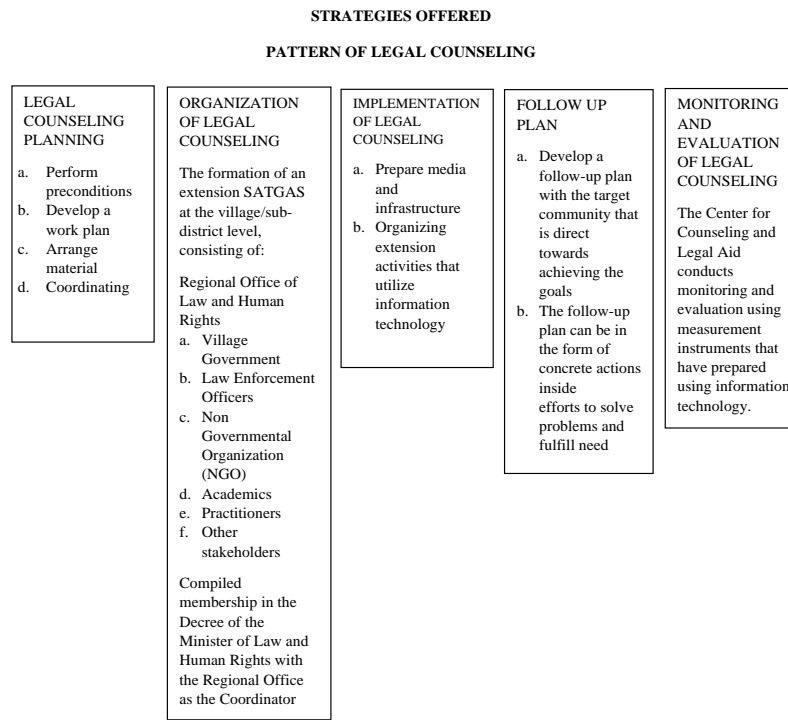

Figure 1 Pattern Of Legal Counseling.
Information:

a. Establishment of a task force (SATGAS) at the Village Level

1) The formation of the Village SATGAS in the Decree by the Minister of Law and Human Rights

2) Regional Offices as Provincial Coordinators

3) It hopes that the arrangement of the SATGAS can become a driving force in his village in transmitting legal understanding and awareness.

4) The Village SATGAS must have a target proven by the follow-up results obtained from the Provincial SATGAS

5) The main task of the village SATGAS is how to transmit an understanding of the law to the community and as a Legal Awareness Professional Revolutionaries.

b. Outreach Programs that Must Have to Follow Up

1) The village SATGAS must have its work program based on the needs of the village

2) The village SATGAS works in synergy by utilizing local communities and technology

3) The village SATGAS targets the education program in its area

c. Monitoring and Evaluation as Measured by Quality Not Quantity

1) Compiled indicators of the quality of understanding and legal awareness

2) Measurements using the $3 \mathrm{~A}$ application with supporting data that can be uploaded

3) Monitoring and evaluation by the provincial coordinator every three months

4) Monitoring and evaluation results can access by the central and regional high leaders.

\section{CONCLUSION}

Based on the above discussion, it is clear that the role of the National Law Development Agency in legal counseling is very important in the development of a legal culture in order to realize public legal awareness. The National Law Development Agency has conducted legal counseling in various ways and methods. The method of legal counseling is direct legal counseling and indirect legal counseling. The results of the implementation of community legal 
counseling conducted by the National Law Development Agency have not met expectations. This role certainly needs to be adjusted to the development of community dynamics and advances in information technology.

Thus, this study recommends implementing a community involvement strategy in legal education. In this context, society is not made an object, but is treated as a subject who actively plays a role with all its innovations. Concrete steps that BPHN need to take is to form SATGAS Village (Law Enforcement Officials, NGOs, Academics and local communities) in carrying out general legal education and civilization aimed at the entire community. SATGAS has a clear and measurable extension work program using technology that is oriented towards follow-up results.

In conducting regular monitoring and evaluation to measure public legal awareness, BPHN needs to develop indicators of legal understanding and awareness by utilizing applications that contain indicators of legal knowledge, understanding, attitudes and patterns of behavior.

\section{AUTHORS' CONTRIBUTIONS}

All authors conceived and designed the study. Josefhin Mareta, Junaidi Abdillah, and Zaihan H. Anggayudha collected the data. Oki Wahju Budijanto analyzed the data and wrote the paper. Oki Wahju Budijanto and Josefhin Mareta contributed to manuscript revisions. All authors approved the final version of the manuscript and accountable for the content therein.

\section{ACKNOWLEDGMENTS}

The authors would like to thank the Head of the Research and Development Agency for Law and Human Rights, who gave the confidence to carry out this research. We also convey thanks to all those who have helped in carrying out this research.

\section{REFERENCES}

[1] B. monitor dan evaluasi 5. 74. desa/kelurahan sadar Hukum, "BPHN monitor dan evaluasi 5.744 desa/kelurahan sadar hukum," 2020. [Online]. Available: https://www.antaranews.com/berita/1559928/bp hn-monitor-dan-evaluasi-5744-desa-kelurahansadar-hukum.

[2] B. P. Statistik, "Statistik Kriminal," Jakarta, 2019.
[3] "Sepanjang 2019, Tingkat Kejahatan Menurun 19\%," 2019. [Online]. Available: https://www.beritasatu.com/faisal-malikibaskoro/nasional/592780/sepanjang-2019tingkat-kejahatan-menurun.

[4] "Angka Kriminalitas di Indonesia Meningkat 38,45 Persen," 2020. [Online]. Available: https://www.lampost.co/berita-angkakriminalitas-di-indonesia-meningkat-38-45persen.html.

[5] M. A. Zaidan, Kebijakan Kriminal. Jakarta: Sinar Grafika, 2016.

[6] M. Fuady, Sosiologi Hukum Kontemporer, Interaksi Kekeuasaan, Hukum, dan Masyarakat. Bandung: Citra Aditya Bakti, 2007.

[7] E. Warassih, Pranata Hukum Sebuah Telaah Sosiologis. Semarang: PT Suryandaru Utama, 2005.

[8] “Kamus Besar Bahasa Indonesia.” pp. 169-170, 2005.

[9] Herman, "Upaya Non Penal dalam Penanggulangan Tindak Pidana Korupsi," HOLREV, vol. 2, no. 1, pp. 306-314, 2018.

[10] B. N. Arief, Masalah Penegakan Hukum dan Kebijakan Hukum Pidana dalam Penanggulangan Kejahatan, Edisi Revisi, First. Kencana Prenada Media Group, 2008.

[11] M. Hamdan, Politik Hukum Pidana. Jakarta: Raja Grafindo Persada, 1997.

[12] "Nawacita 9 Agenda Prioritas Jokowi-JK," Warta Kota, Jakarta, 2014.

[13] BPHN, "Laporan Kinerja BPHN Kementerian Hukum dan HAM,” 2019.

[14] Y. Ernis, “Implikasi Penyuluhan Hukum Langsung Terhadap Peningkatan Kesadaran Hukum Masyarakat," Penelit. Huk. JURE, vol. 18, no. 4, pp. 477-496, 2018.

[15] T. N. Wulandari, "Kajian Terhadap Efektifitas Pembentukan Dan Pembinaan Kelurahan Sadar Hukum Dalam Upaya Meningkatkan Kepatuhan Hukum Masyarakat (Studi Kota Pontianak)," Nestor Magister Huk., vol. 1, no. 1, 2017.

[16] S. I. A. Dwiningrum, Desentralisasi dan Partisipasi Masyarakat Dalam Pendidikan. Yogyakarta: Pustaka Pelajar, 2011.

[17] S. Wijaksono, "Pengaruh lama tinggal terhadap 
tingkat partisipasi masyarakat dalam pengelolaan lingkungan permukiman," ComTech, vol. 4, no. 1, p. 27, 2013.

[18] Jawardi, "Strategi Pengembangan Budaya Hukum," Penelit. Huk. JURE, vol. 16, no. 1, pp. 77-93, 2016.

[19] N. A. Purwatiningsih, A. F, and R. S. H. M, "Pemanfaatan Internet dalam Meningkatkan Kinerja Penyuluh Pertanian di Kabupaten Cianjur," Penyuluhan, vol. 14, no. 1, pp. 79-91, 2018.

[20] P. P. S. K. Sosial, Panduan Penyuluhan Sosial. Jakarta, 2019. 